\title{
UWARUNKOWANIA RODZINNE ZACHOWAŃ RYZYKOWNYCH DZIECI I MŁODZIEŻY - ANALIZA WYBRANYCH CZYNNIKÓW
}

\begin{abstract}
Streszczenie: Tekst dotyczy uwarunkowań rodzinnych jako głównego źródła zachowań ryzykownych młodzieży. Na podstawie przeglądu (wybranych) badań dokonałam analizy najważniejszych czynników związanych z rodziną, mających wpływ na przejawy zachowań ryzykownych dzieci i młodzieży. Były to m.in. czynniki ryzyka o charakterze patologicznym (problemy nadużywania alkoholu w rodzinie, narkotykowy, agresja, przemoc) oraz nieposiadające znamion patologii (migracja zarobkowa rodziców, niewłaściwa kontrola rodzicielska bądź jej brak). W podsumowaniu ogólnie odniosłam się również do innych czynników, które mogą wpływać na zachowania ryzykowne podejmowane przez dzieci i młodzież). W części końcowej tekstu skonstruowałam pewne propozycje zaleceń, które mogą być przydatne w działaniach profilaktyczno-terapeutycznych związanych z zachowaniami problemowymi nieletnich.
\end{abstract}

Słowa kluczowe: zachowania ryzykowne (problemowe), rodzina, wychowanie, migracja zarobkowa, problem nadużywania alkoholu, kontrola rodzicielska.

\section{Wprowadzenie}

Zachowania ryzykowne mają swoje podłoże w różnych obszarach życia i funkcjonowania człowieka. Badacze wskazują na wiele teorii i koncepcji odnoszących się do poszukiwania źródeł zachowań ryzykownych. Edward O. Wilson (1988, s. 150-151) wskazuje, że zachowania ryzykowne kształtują się pod wpływem kultury i nie podlegają dziedziczeniu. Mogą być one skutkiem napięcia emocjonalnego wywołanego różnymi sytuacjami frustracyjnymi doświadczanymi przez człowieka. Zdaniem Alberta Bandury oraz Richarda H. Waltersa (2007, s. 29-30), są one modelowane w wyniku obserwacji oraz uczenia się podmiotu działań podejmowanych przez osoby pełniące rolę "modela” i skutków tych działań. Z kolei teoria zachowań problemowych Richarda i Shirley Jessorów odnosi się do konfrontowania zachowań 
ryzykownych z zachowaniami konwencjonalnymi. Autorzy wskazują na to, że zachowania ryzykowne służą zaspokajaniu tych samych potrzeb co zachowania konwencjonalne (np. potrzeby miłości, akceptacji). Pozwalają realizować te same cele rozwojowe (cyt. za: Przybysz-Zaremba 2015, s. 5-6). Młodzież, sięgając np. po substancje psychoaktywne, spodziewa się doświadczyć różnych afirmatywnych korzyści, które mają charakter krótkotrwały, ale pomimo to są ważne w ich życiu (mają dla nich wielkie znaczenie). Młodzi ludzie nie zastanawiają się nad negatywnymi oddziaływaniami na organizm substancji psychoaktywnych, gdyż implikacje tego mogą ujawnić się dopiero w odległym czasie. Ryzykowne zachowania są przez nich podejmowane z własnej i nieprzymuszonej woli, pomimo iż są niebezpieczne dla ich życia i zdrowia (Irwin 1990, s. 1-14).

Termin „zachowania ryzykowne” odnosi się do zachowań negatywnych (pejoratywnych), potencjalnie szkodliwych dla zdrowia. Są to działania podejmowane przez jednostkę z własnej woli, których implikacje mają najczęściej charakter negatywny. Negatywne konsekwencje zachowań ryzykownych badacze analizują zarówno w wymiarze psychofizycznego zdrowia jednostki, jak i jej otoczenia (Szymańska 2012, s. 11).

Na gruncie nauk społecznych występuje heterogeniczność terminów pokrewnych, niekiedy zamiennie stosowanych przez naukowców w rozważaniach i eksploracjach nad ryzykownymi zachowaniami dzieci, młodzieży oraz dorosłych. Używane są m.in. takie określenia, jak: „zachowania problemowe”, „zaburzenia zachowania”, „zachowania dewiacyjne”, „niedostosowanie społeczne”, „wykolejenie społeczne”, „patologia zachowania”, „trudności wychowawcze”, „zaniedbanie moralne" (cyt. za: Przybysz-Zaremba 2015, s. 5). Wszystkie te sformułowania wprowadzają pewnego rodzaju chaos, który powoduje trudności w sformułowaniu jedynej definicji odnoszącej się do ryzykownych zachowań.

Źródeł zachowań problemowych (ryzykownych) młodzieży jest nieskończenie wiele. Badania wskazują m.in. na grupy zintegrowanych faktorów związanych z obszarami życia i funkcjonowania młodzieży, tj. środowiskiem szkolnym ${ }^{1}$, społecznym, grupą rówieśniczą, oddziaływaniem mediów oraz środowiskiem rodzinnym (rodziną). Wskazuje się również na grupy faktorów ściśle związanych z jednostką. Są to m.in. czynniki biologiczne i psychologiczne, takie jak: „czas dojrzewania płciowego, predyspozycje genetyczne, małe, często poniżej normy

${ }^{1}$ Do czynników ryzyka związanych ze środowiskiem szkolnym młodzieży, jako predykatorów do ujawniania zachowań ryzykownych, zalicza się zarówno czynniki związane z systemem edukacyjnym i nauczycielem, jak i odnoszące się do rówieśników/kolegów z klasy. Są to m.in.: wymagania względem nauki, którym uczeń nie jest w stanie sprostać, problemy w nauce i zbyt wygórowane wymagania, konflikty z nauczycielami, kolegami i koleżankami, doświadczanie agresji i/lub przemocy ze strony nauczycieli oraz rówieśników, brak akceptacji w grupie klasowej, osamotnienie itp. (Sznitman, Romer 2014, s. 65-73; Przybysz-Zaremba, Katkonienè 2014, s. 48-62). 
zdolności, zaburzenia koncentracji, zaburzenia psychoruchowe, zaburzenia emocjonalne, niskie poczucie własnej wartości” (Przybysz-Zaremba 2015, s. 6).

Ze względu na obrany tytuł opracowania analizie poddane zostaną (wybrane) czynniki stricte związane ze środowiskiem rodzinnym (rodziną) młodzieży. A zatem celem tekstu jest wskazanie na najważniejsze czynniki związane z rodziną (niekiedy tkwiące w rodzinie) jako predyktory do ujawniania zachowań ryzykownych młodzieży. Ze względu na wielość i różnorodność, a często także integralność czynników związanych z rodziną - jako ważnego źródła zachowań problemowych (ryzykownych) młodzieży - odniosłam się, na podstawie przeglądu wielu badań, do analizy jedynie wybranych czynników, z którymi współcześnie często mamy do czynienia w rodzinie. Są to m.in.: migracja zarobkowa rodziców, problem alkoholowy (narkotykowy) w rodzinie, agresja, przemoc oraz niewłaściwa kontrola rodzicielska. W podsumowaniu dokonałam ogólnego zarysu również innych czynników związanych z rodziną, mających wpływ na ujawnianie zachowań ryzykownych, a także skonstruowałam zalecenia pomocne $\mathrm{w}$ minimalizowaniu zachowań problemowych nieletnich.

\section{Rodzina jako źródło zachowań ryzykownych dzieci i młodzieży - przegląd wybranych czynników na podstawie badań}

Rodzina to fundamentalne środowisko życia dziecka. Jest ona składnikiem systemu wychowawczego, który stanowi niezbędny faktor holistyczno pojmowanej socjalizacji, obejmującej wszelkie wpływy i oddziaływania czynników w niej tkwiących na jednostkę. Często w sposób spontaniczny, samorzutny i mimowolny kształtuje środowisko kulturowe dziecka, które uzewnętrznia się m.in. w stylu życia, indywidualnym sposobie wyrażania siebie, swoich uczuć, myśli, nawyków oraz własnego słownictwa (Przybysz-Zaremba 2016, s. 84-85). Jest to środowisko, w którym tkwi wiele czynników, zarówno o charakterze tzw. „pozytywnym”, jak i „negatywnym”, rzutujących niekiedy na całe życie jednostki.

Ze względu na obrany temat opracowania uwaga moja skupiona zostanie na czynnikach o charakterze negatywnym (pejoratywnym), jako istotnych uwarunkowaniach zachowań ryzykownych młodzieży szkolnej, stricte związanych z rodziną. Podkreślić tu jednak należy, że w rodzinie tkwi wiele negatywnych czynników (nie tylko o charakterze patologicznym, takich jak: problem alkoholowy, narkotykowy, agresja, przemoc itp.), ale również różnego rodzaju zaniedbań wychowawczych względem dzieci i młodzieży, które poniekąd mają swoje podłoże w przemianach cywilizacyjnych i przeobrażeniach społecznych i w większym lub mniejszym stopniu oddziałują na rodzinę. Ze względu jednak na ograniczenia związane z wymogami publikacyjnymi tekstu prześledzenie wszystkich tych czynników jest niemożliwe. A zatem analizie poddałam (wybrane) badania (głównie zagraniczne) dotyczące takich czynników związanych z rodziną, jak: migracja zarobkowa, 
problem alkoholowy, agresja, przemoc, kontrola rodzicielska (niewłaściwa bądź całkowity jej brak).

Alexander T. Vazsonyi, Elizabeth Trejos-Castillo oraz Maureen A. Young (2008, s. 798-811) podjęli się próby poszukiwania etiologii zachowań problemowych wiejskiej młodzieży amerykańskiej. Badaniem objęto 687 osób, których wiek średni wynosił 15,8 lat. Analizowano m.in. czynniki predykcyjne ściśle związane z rodziną a odnoszące się do wychowania, takie jak: monitorowanie, wsparcie, komunikacja, czynniki związane z grupą rówieśniczą oraz sąsiedztwem. Badania wskazują, że zaburzenia występujące $\mathrm{w}$ omawianych grupach, $\mathrm{z}$ których rodzina jest najważniejszą $\mathrm{z}$ nich (występuje w niej wiele pejoratywnych czynników prowadzących do „zaburzeń rodzicielskich", zaburzeń dewiacyjnych), prowadzą do różnorodnych zachowań problemowych młodzieży. Najczęściej wskazywanymi były: spożywanie alkoholu, zażywanie narkotyków, przestępczość, przemoc. Należy tu podkreślić, że często zachowania ryzykowne przejmowane $w$ rodzinie przez dzieci, przenoszone są na inne obszary funkcjonowania (np. do grupy rówieśniczej, grupy klasowej itp.) i vice versa.

Jednym z istotnych czynników, który często występuje we współczesnych rodzinach, jest migracja zarobkowa rodzica bądź obojga rodziców. Rodzina ze względu na trudną sytuację ekonomiczną zmuszona jest podjąć decyzję o wyjeździe - coraz częściej jest to wyjazd zagraniczny. W tym przypadku rodzina na pierwszym miejscu stawia realizację funkcji ekonomicznej, niestety mocno zaniedbując funkcję wychowawczo-socjalizacyjno-opiekuńczą. W tym zakresie przeprowadzono wiele badań, które wskazują na różne skutki migracji zarobkowej rodziców. Badania prowadzili m.in. badacze chińscy ${ }^{2}$ (Shuang Lu, Yi-Ting Lin, Juliann H. Vikse oraz Chien-Chung Huang (2016, s. 58-68), którzy analizowali wpływ migracji zarobkowej rodziców oraz ich status ekonomiczny na edukację, zdrowie, nadzór rodzicielski oraz kształtowanie się wartości dzieci i młodzieży. Wyniki ich badań wskazują na wiele różnych zaniedbań ze strony migrujących rodziców, które mają istotny wpływ na edukację, rozwój i funkcjonowanie dzieci i młodzieży. W oparciu o te badania wysunięto propozycję opracowania zmian polityki socjalnej kraju, wprowadzenia nowych programów oraz świadczeń i usług skierowanych bezpośrednio do ludności migrującej. Badacze zwrócili uwagę na konieczność rozwiązywania problemów wynikających bezpośrednio z migracji, która występuje w różnych krajach, stając się wewnętrznym lub nawet międzynarodowym problemem.

Rozpatrując migrację zarobkową rodziców w kontekście jej skutków, bezpośrednio doświadczanych przez dzieci i młodzież, należy zwrócić uwagę na fakt, że rozłąka rodziców z dziećmi prowadzi do „pęknięcia” więzi rodzicielskiej i wielu zaburzeń w zachowaniu i funkcjonowaniu młodzieży (w tym również dzieci).

${ }^{2} \mathrm{~W}$ Chinach miliony dzieci wiejskich pozostawionych jest samych w domach, ponieważ ich rodzice migrują do miast w poszukiwaniu pracy. Dzieci te samodzielnie wykonują wszelkie obowiązki, doświadczają przy tym wiele problemów emocjonalnych związanych z rozłąką z rodzicami. Zob. Murphy 2014, s. 29-51. 
Zaburzeniu ulegają m.in. relacje z kolegami, rówieśnikami, nauczycielami, a przede wszystkim z rodzicami, co w znacznym stopniu uzewnętrznia wiele problemów i zachowań ryzykownych przejawianych przez nieletnich. Młodzież bez nadzoru i kontroli rodziców sama decyduje o tym, co będzie robić. Z powodu doświadczania samotności często „ucieka w świat wirtualny” (o ile ma taką możliwość), który pomaga jej funkcjonować. Spędza tam dużo czasu (w praktyce często jest to czas nieograniczony). Nieustanna i długotrwała wędrówka po „wirtualnym świecie" dostarcza młodemu człowiekowi efektu euforii, a następnie spokoju, które w krótkim czasie przeradzają się w zastępowanie, ucieczkę oraz „socjomanię internetową" (Guo i in. 2015). Najbardziej podatni na internetowe uzależnienia są ludzie dotknięci „zespołem niedoboru nagradzania”, a więc dzieci i młodzież zaniedbane wychowawczo wpisują się w tę grupę doskonale (Przybysz-Zaremba 2010, s. 128-135).

Kolitha Wickramage, Chesmal Siriwardhana i in. (2015, s. 39) wskazują, że migracja zarobkowa rodziców negatywnie oddziałuje na psychikę dzieci, szczególnie tych, które nie osiągnęły jeszcze 12 roku życia. Dzieci wychowywane w gospodarstwach domowych w Indonezji oraz Tajlandii, których matki „oddawały się" migracji zarobkowej, miały znacznie uboższe samopoczucie psychiczne niż te dzieci, których matki nie migrowały (Graham, Jordan 2011, s. 763-787), chociaż badania przeprowadzone przez G. Battistella oraz M.C.G. Conaco wśród uczniów szkół filipińskich wskazują na to, że brak jest „mocnych danych”, które w sposób jednoznaczny potwierdziłyby, że dzieci rodzin migrujących mają większe problemy psychologiczne niż dzieci rodziców niemigrujących. Badacze podają, że nieobecność matki może powodować problemy behawioralne u dzieci, ale nie zawsze można o tym mówić w przypadku migracji zarobkowej ojca. Tymczasem ponad 50 proc. ludności migrującej na Filipinach stanowią mężczyźni (Battistella, Conaco 1998, s. 220-241).

Istotnym elementem analizowanym w badaniach dotyczących skutków migracji zarobkowej rodziców jest odżywianie się dzieci i młodzieży. Badania przeprowadzone przez M. Camerona i S. Lin (2007) w Tajlandii wskazują, że brak jednego $\mathrm{z}$ rodziców w gospodarstwach domowych migrujących ma negatywny wpływ na krótkoterminowe żywienie dzieci. Autorzy podkreślają, że można ten problem zminimalizować wzrostem poziomu przekazów środków pieniężnych na rzecz gospodarstwa domowego, w którym funkcjonują pozostali członkowie rodziny.

Obok migracji zarobkowej w wielu rodzinach często występuje mnóstwo czynników o charakterze patologicznym, które mogą mieć swoje podłoże zarówno w faktorach o charakterze makro-, jak i mikrospołecznym. Jednym z takich czynników jest problem alkoholowy. Alkohol często traktowany jest przez dorosłych jako „wyzwalacz” zachowań agresywnych i przemocowych w stosunku do bliskich. W tym zakresie badacze przeprowadzili wiele badań, które potwierdzają negatywne oddziaływanie alkoholizmu w rodzinie na (dzieci) młodzież. T. Sarkola i in. (2007, s. 1571-1576) udowadniają, że dziecko poddawane w okresie prenatalnym działaniom 
alkoholu (lub narkotykom) doświadcza wielu negatywnych skutków, które określa się jako poalkoholowe spektrum zaburzeń rozwojowych (fetal alcohol spectrum disorder, FASD), spektrum wrodzonych anomalii strukturalnych i neurokognitywnych oraz behawioralnych. W początkowym okresie życia u dzieci tych zaobserwować można różne anomalie fizyczne, opóźnienia w rozwoju, nieprawidłowości w rozwoju układu nerwowego, poalkoholowe wady wrodzone oraz poalkoholowe zaburzenia neurorozwojowe itp. W okresie wzrastania dziecka ujawniają się zaburzenia charakterystyczne dla zespołu FASD. Są to m.in. zaburzenia rozwoju psychicznego, które przekładają się na słabe wyniki w nauce ${ }^{3}$, przejawianie trudności wychowawczych, zachowania agresywne i/lub przemocowe oraz wszelkie inne symptomy niedostosowania społecznego, które prowadzą do wykolejenia (Przybysz-Zaremba 2015a, s. 243-260). U dzieci występuje też ryzyko pojawienia się nadpobudliwości psychoruchowej (ADHD), a także tzw. „wtórnych zaburzeń” typu: nieodpowiednie zachowania seksualne, problemy w funkcjonowaniu społecznym, uzależnienia od substancji psychoaktywnych, w tym od alkoholu, tytoniu (Clark i in. 2004, s. 1-12). Dzieci te wcześnie podejmują inicjację seksualną. Badacze (Benvegnu i in. 2005, s. 1417-1424) podają, że zachowania tego typu dwa razy częściej przejawiane są przez dzieci i młodzież, wobec których rodzice stosowali restrykcyjne metody wychowawcze, $w$ tym kary fizyczne. Potwierdzają to również badania przeprowadzone przez Chrisa Taplina i in. (2014, s. 1311-1316), z których wynika, że doświadczanie dzieciństwa przepełnionego agresją, przemocą, „maltretowaniem", a niekiedy i wykorzystywaniem seksualnym ma wiele negatywnych konsekwencji, które widoczne są nie tylko w okresie dzieciństwa i rozwoju, ale często utrzymują się również w okresie dorosłym (niekiedy się nasilają). Z badań przeprowadzonych na grupie 87 pacjentów zgłoszonych na leczenie uzależnienia od alkoholu i narkotyków wynika, że nałogi, których doświadczają, są ściśle związane $\mathrm{z}$ doznawanym $\mathrm{w}$ dzieciństwie wykorzystywaniem seksualnym, z przemocą emocjonalną i fizyczną, jak również wszelkiego rodzaju zaniedbaniami ze strony rodziców (rodziny). Im wcześniej dzieci mają do czynienia z alkoholem bądź narkotykami, tym wskaźnik ciężkości przebiegu uzależnienia (ASI) jest wyższy. Integracja tych czynników w sposób negatywny oddziałuje na rozwój i wychowanie dzieci i młodzieży (Taplin i in. 2014, s. 1311-1316).

Zespół badaczy kierowany przez Jennifer C. Elliott (2012, s. 1774-1785) wykazał, że rodzina z problemem alkoholowym (bądź narkotykowym) kształtuje destrukcyjne wzorce zachowania dziecka, które poddawane oddziaływaniom innych negatywnych czynników środowiska społecznego, mogą uwidaczniać się

\footnotetext{
${ }^{3}$ Badania przeprowadzone wśród dzieci w wieku wczesnoszkolnym wskazują na to, że dzieci poddawane w okresie prenatalnym działaniom alkoholu mają ubytek siedmiu punktów IQ. Dzieci te, w stosunku do dzieci z grupy kontrolnej, są znacznie słabsze w zakresie czytania, ortografii, dodawania, odejmowania, świadomości fonologicznej i innych testów wczesnych umiejętności (Asher, Zivanit 2010, s. 364-379).
} 
w dorosłym życiu (a w indywidualnych przypadkach nawet znacznie wcześniej) (zob. też: Dielmann i in. 1993, s. 273-316; Arcidiacono i in. 2010, s. 659-680).

Jak wiadomo ${ }^{4}$, rodzina $\mathrm{z}$ problemem alkoholowym nie realizuje prawidłowo funkcji opiekuńczo-wychowawczych względem dzieci i młodzieży, co prowadzi do wielu zaburzeń w ich zachowaniu, a w przypadku dzieci do piątego roku życia także do wielu problemów zdrowotnych. Do czynników ryzyka przyczyniających się do zaburzeń i problemów zdrowotnych dzieci i młodzieży należą: psychopatologia rodzicielska, stres rodzicielski, negatywne postrzeganie dziecka przez matkę; status społeczno-ekonomiczny rodziny, problemy małżeńskie rodziców, zaburzone relacje, przemoc, patologie i inne problemy rodziny. Badacze wskazują także na czynniki, które stricte związane są z dzieckiem, np. temperament niemowlęcia, wczesne objawy emocjonalne i behawioralne dziecka (uzewnętrznianie i internalizacja), które mogą kształtować się poprzez niewłaściwe zachowania rodziców w stosunku do dziecka (Mantymaa i in. 2012, s. 153-170).

Zachowania ryzykowne młodzieży ujawniają się także w wyniku niewłaściwej kontroli rodzicielskiej. Zarówno jej nadmiar, jak i brak sprzyjają uzewnętrznianiu się zachowań problemowych (ryzykownych). Aspekt ten badacze analizowali m.in. ze względu na płeć. I tak np. w przypadku chłopców brak kontroli rodzicielskiej sprzyja sięganiu po alkohol (głównie piwo) i częstym upijaniu się w towarzystwie rówieśników, co tym samym sprzyja rozpoczęciu wczesnego współżycia seksualnego. W przypadku dziewcząt natomiast brak kontroli sprzyja zażywaniu amfetaminy, paleniu papierosów, piciu alkoholu (głównie piwa), a często i upijaniu się. W takim stanie dziewczęta równie często podejmują wczesną inicjację seksualną (Przybysz-Zaremba - tekst w druku). Z kolei nadmierna kontrola rodzicielska powoduje, że młodzi ludzie interpretują ją jako „ingerowanie” dorosłych w ich życie. Zdolność symbolizowania, wyrażania siebie, własnych myśli i uczuć jest wówczas ograniczona (Barber, Harmon 2002, s. 15-52). U młodzieży mogą ujawniać się wtedy zachowania buntowniczo-agresywne, pojawiać się złość, wyższy poziom samokrytyki, co będzie implikowało niską samooceną, rozwojem lęków, depresji, a nawet myślami samobójczymi (Bebes i in. 2015, s. 882-890). Zbyt wysoki poziom kontroli - głównie psychologicznej - przejawiającej się we wzmacnianiu ustalonych norm, może zniechęcać nieletnich do podejmowania wszelakich działań, a zarazem motywować do ujawniania różnych zachowań problemowych.

\section{Zalecenia w zakresie minimalizowania zachowań ryzykownych dzieci i młodzieży - tytułem podsumowania}

Rodzina to priorytetowe środowisko życia i funkcjonowania (dzieci) młodzieży, w którym tkwi wiele różnorodnych czynników wzajemnie na siebie oddziałujących, tworzących bogate a zarazem zintegrowane spektrum faktorów, nie zawsze

\footnotetext{
${ }^{4}$ Potwierdzają to również badania, do których odwołuję się w tekście.
} 
w sposób właściwy oddziałujących na nieletnich. W wielu przypadkach stają się one predykatorami do ujawniania zachowań ryzykownych. Nie zawsze są to czynniki o charakterze destrukcyjnym czy patologicznym, ale coraz częściej nie posiadają one znamion patologicznych. Do czynników niepatologicznych zalicza się m.in.: złe warunki materialno-bytowe, brak pracy skutkujący ubóstwem, nędzą, wykluczeniem społecznym rodziny, migrację zarobkową itp., co przekłada się na zaburzenia w funkcjonowaniu całego systemu rodziny. Czynniki te w sposób dynamiczny zaburzają przede wszystkim komunikację w rodzinie, która prowadzi do braku zainteresowania się rodziców sprawami dzieci. Z kolei brak kontroli rodzicielskiej wpływa na ujawnianie się różnego rodzaju zachowań ryzykownych. Do głównych czynników o charakterze patologicznym natomiast zaliczają się: nadużywanie alkoholu w rodzinie (alkoholizm), zażywanie narkotyków, agresja i przemoc. Należy tu jednak zaznaczyć, że problemy te często prowadzą do podejmowania przez rodziców innych zachowań destrukcyjnych, jak np. molestowania czy wykorzystywania seksualnego nieletnich. W tekście trudno odnieść się do nich wszystkich. A zatem podejmuję jedynie temat wybranych czynników, które w moim przekonaniu najczęściej występują we współczesnej rodzinie. Trzeba zwrócić uwagę również na to, iż czynniki, o których jest tu mowa, rzadko występują w postaci „czystej”, ale często wiele faktorów społecznych kształtuje zaburzenia całego systemu rodziny.

Podsumowując, zachowania ryzykowne przejawiane przez nieletnich mają swój "pierwotny zalążek” w rodzinie, która dla dziecka stanowi fundamentalne środowisko życia. Stąd też wszelkie działania profilaktyczno-terapeutyczne, dotyczące minimalizowania zachowań ryzykownych, należy rozpocząć od rodziny. Działania te powinny obejmować:

- kształtowanie prawidłowej komunikacji w rodzinie, która - od wczesnego okresu życia dziecka - powinna opierać się na rozmowie, wsparciu, zachęcaniu i motywowaniu (dzieci) młodzieży do rozwijania i wyrażania własnych myśli, zainteresowań i pomysłów (autonomii) (Kunz, Grych 2013, s. 77-94);

- podejmowanie przez rodziców wszelkich działań mających na celu utrzymywanie pozytywnych więzi emocjonalnych z dzieckiem (Kunz, Grych 2013, s. 77-94);

- „wZajemność" rodziców w realizowanym procesie socjalizacji, a w przypadku rozłąki związanej z migracją zarobkową - wzajemne uzupełnianie się i wspieranie; - udział szkoły i innych instytucji specjalistycznych w pomocy i wsparciu całej rodziny doświadczającej migracji zarobkowej, w tym przede wszystkim dzieci i młodzieży borykających się z różnego rodzaju problemami;

Szkoła - jako „profesjonalna” instytucja - powinna:

- aktywnie uczestniczyć w organizowaniu zajęć (warsztatów) edukacyjno-informacyjnych, skierowanych do rodziców i uczniów przejawiających zachowania ryzykowne, mających na celu kształtowanie czynników wzmacniających (bezpieczeństwo, wsparcie) prawidłowe funkcjonowanie dziecka/młodzieży, które w wyniku migracji rodziców uległy osłabieniu; 
- prowadzić systematyczną obserwację zachowań uczniów, a w przypadku tzw. „uczniów problemowych”, objąć ich staranną opieką i wsparciem;

- natychmiast interweniować w przypadku zdiagnozowania zachowań ryzykownych nieletnich i podejmować różne działania profilaktyczno-terapeutyczne, uwzględniające zasoby wewnętrzne uczniów;

- wskazywać na możliwości pomocy i wsparcia ucznia i jego rodziny, która doświadcza problemów patologicznych (problemu nadużywania alkoholu, agresji, przemocy itp.).

\section{Bibliografia}

Arcidiacono C., Velleman R., Procentese F., Berti P., Albanesi C., Sommantico M., Copello A. (2010). Italian families living with relatives with alcohol or drugs problems. „Drugs: Education, Prevention \& Policy”, vol. 17, issue 6, s. 659-68o. Asher O., Zivanit E. (2010). Alcohol Abuse in Pregnant Women: Effects on the Fetus and Newborn, Mode of Action and Maternal Treatment. „International Journal of Environmental Research and Public Health", nr 2, vol. 7, s. 364-379.

Bandura A. (2007). Teoria społecznego uczenia się. Warszawa: PWN.

Barber B. K., Harmon E. L. (2002). Violating the self: Parental psychological control of children and adolescents. W: Barber B. K. (red.). Intrusive parenting: How psychological control affects children and adolescents. Washington DC: American Psychological Association, s. 15-52.

Battistella G., Conaco M. C. G. (1998). The Impact of Labour Migration on the Children Left Behind: A study of elementary school children in the Philippines. „Journal of Social Issues in Southeast Asia", nr 2, vol. 13, s. 220-241.

Bebes A., Samarova V., Shilo G., Diamond G. M. (2015). Parental Acceptance, Parental Psychological Control and Psychological Symptoms Among Sexual Minority Adolescents. „Journal of Child and Family Studies", nr 24, s. 882-89o.

Benvegnu L. A., Fassa A. G., Facchini L. A., Wegman D. H., Dall' Agnol M.M. (2005). Work and behavioural problems in children and adolescents. „International Journal of Epidemiology", nr 6, vol. 34, s. 1417-1424.

Cameron M., Lim S. (2007). Household resources, household composition, and child nutritional outcomes. W: Conference Presentation, Australian Agricultural and Resource Economics Society Conference.

Clark E., Lutke J., Minnes P., OuelletteKuntz H. (2004). Secondary disabilities among adults with fetal alcohol spectrum disorder in British Columbia. „Journal of FAS International", vol. 2 (e13), s. 1-12.

Dielmann T. E. i in. (1993). Structural equation model tests of patterns of family interaction, peer alcohol use, and intrapersonal predicators of adolescent alcohol use and misuse. „Journal of Drug Education”, nr 3, vol. 23, s. 273-316. 
Elliott J. C., Carey K. B., Bonafide K. E. (2012). Does family history of alcohol problems influence college and university drinking or substance use? A meta-analytical review. „Addiction”, vol. 107, issue 10, s. 1774-1785.

Guo J., Ren X., Wang X., Qu Z., Zhou Q., Ran Ch., Wang X., Hu J. (2015). Depression among Migrant and LeftBehind Children in China in Relation to the Quality of Parent-Child and Teacher-Child Relationships. PLoS ONE 10 (12).

Graham E. Jordan L. P. (2011). Migrant parents and the psychological well-being of left-behind children in Southeast Asia. „J Marriage Fam.", vol. 73, s. 763-87.

Irwin C. E. jr. (1990). The Theoretical Concept of At-risk Adolescents. „Adolescent Medicine: State of the Art Reviews", nr 1, s. 1-14.

Kunz J. H., Grych J. H. (2013). Parental Psychological Control and Autonomy Granting: Distinctions and Associations with Child and Family Functioning. „PARENTING, SCIENCE AND PRACTICE”, nr 13, s. 77-94.

Lu S., Lin Yi-Ting, Vikse J. H., Huang Chien-Chung (2016). Well-being of migrant and left-behind children in China: Education, health, parenting, and personal values. „International Journal of Social Welfare”, nr 1, vol. 25, s. 58-68.

Mantymaa M., Puura K., Luoma I., Latva R., Salmelin R. K., Tamminen T. (2012). Predicting Internalizing and Externalizing Problems at Five Years by Child and Parental Factors in Infancy and Toddlerhood. "Child Psychiatry and Human Development", nr 2, vol. 43, s. 153-170.

Murphy R. (2014). Study and School in the Lives of Children in Migrant Families: A View from Rural Jiangxi, China. „Development \& Change”, nr 1, vol. 45, S. 29-51.

Przybysz-Zaremba M. (2016). Komponenty rodziny jako istotne stymulatory dla rozwoju zainteresowań, ujawniania zdolności i talentów dziecka - wybrane aspekty i badania. W: G. Cęcelek, M. Potoczna, M. Przybysz-Zaremba (red.). RodzinaSzkoła-Środowisko społeczne - obszary kształtowania kreatywności i twórczości dziecka (ucznia). Skierniewice: Wydawnictwo PWSZ w Skierniewicach.

Przybysz-Zaremba M. (2015). Zachowania ryzykowne dzieci i młodzieży - eksplikacje, kontemplacje, egzemplifikacje, eksplikacje. Tytułem wprowadzenia. W: Przybysz-Zaremba M. (red.). Zachowania ryzykowne dzieci i młodzieży. Heterogeniczny wymiar oddziaływań profilaktycznych. Wybrane aspekty, Olsztyn: Wydawnictwo PROSPEKT PR.

Przybysz-Zaremba M. (2015a). Dymorficzny wymiar uwarunkowań agresji i przemocy domowej - przegląd wybranych aspektów $i$ eksploracji. „Studia nad Rodziną", nr 2 (37), s. 243-26o.

Przybysz-Zaremba M. (2010). Internet zagrożeniem dla dzieci i młodzieży. W: R. Reclik, A. Zduniak (red.). Jakość wobec wyzwań i zagrożeń XXI wieku. Poznań: Wydawnictwo Wyższej Szkoły Bezpieczeństwa.

Przybysz-Zaremba M. Kontrola rodzicielska a zachowania ryzykowne dzieci i młodzieży - wybrane aspekty i badania. „Pedagogika Społeczna” (tekst po recenzji, przyjęty do druku). 
Przybysz-Zaremba M., Katkonienè A. (2014). Profilaktyka agresji i przemocy w szkole w optyce edukacyjnej. „Społeczeństwo i Rodzina”, nr 1, vol. 38, s. 48-62.

Sarkola T., Kahila H., Gissler M., Halmesmaki E. (2007). Risk factors for out-of-home custody child care among families with alcohol and substance abuse problems. „Acta Pædiatrica”, nr. 96, s. 1571-1576.

Sznitman S. R., Romer D. (2014). Student Drug Testing and Positive School Climates: Testing the Relation Between Two School Characteristics and Drug Use Behavior in a Longitudinal Study. „Journal of Studies on Alcohol \& Drugs”, nr 1, vol. 75, s. $65-73$.

Szymańska J. (2012). Programy profilaktyczne. Podstawy profesjonalnej psychoprofilaktyki. Warszawa: Ośrodek Rozwoju Edukacji.

Vazsonyi A. T., Trejos-Castillo E., Young M. A. (2008). Rural and Non-Rural African American Youth: Does Context Matter in the Etiology of Problem Behaviors? „Journal of Youth and Adolescence”, vol. 37, no. 7, s. 798-811.

Wickramage K., Siriwardhana C. i in. (2015). Risk of mental health and nutritional problems for left-behind children of international labor migrants. „BMC Psychiatry", no. 3, vol. 15, s. 39.

Wilson E. O. (1988). O naturze ludzkiej. Szacka B. (tłum.). Warszawa: PIW.

\title{
FAMILY-RELATED CONDITIONING OF RISKY BEHAVIOURS OF CHILDREN AND YOUTH - ANALYSIS OF SELECTED FACTORS
}

\begin{abstract}
The text considers the family determinants as the main source of youth risky behaviours. On the basis of chosen research papers I have made a review of the most important factors related to family, which have influence on the displays of minors' risky behaviours. Among others, they included factors of the risk of pathological characteristics (problem of alcohol abuse in the family, drug problems, aggression, violence) and the factors which do not qualify as pathological (parents' economic migration, improper parental control or lack of such). In the conclusion I also referred to some other determinants which can trigger risky behaviours of youth. The final part of this text provides some suggestions which can be useful for prevention and therapeutic actions related to youths' risky behaviours.
\end{abstract}

Keywords: risky (problem) behaviours, family, upbringing, economic migration, problem of alcohol abuse, parental control.

Małgorzata Przybysz-Zaremba - doktor habilitowana, profesor nadzwyczajna Uniwersytetu Kardynała Stefana Wyszyńskiego w Warszawie. Wydział Studiów nad Rodziną, kierownik Katedry Pedagogiki Rodziny. Pedagog społeczny. Jej zainteresowania naukowe osadzone są w pedagogice społecznej, pedagogice rodziny, resocjalizacji oraz pracy socjalnej. Autorka licznych publikacji naukowych wydanych w kraju oraz zagranicą, 
a także monografii: Rodzina, praca, edukacja - obszary przestrzeni życia kobiet. Sukcesy, konflikty, problemy (Elbląg 2013), Uzależnienie młodzieży od współczesnych mediów (Olsztyn 2008), Terapia profesjonalna i samopomocowa w uzależnieniu alkoholowym (Olsztyn 2006), oraz redaktorka i współredaktorka takich książek, jak: Family versus post-modernity challanges. Upbringing. Problems. Assistance and Support (Warszawa 2016), Rodzina-SzkołaŚrodowisko społeczne - obszary kształtowania kreatywności i twórczości dziecka (ucznia) (Skierniewice 2016), Zachowania ryzykowne dzieci i młodzieży. Heterogeniczny wymiar oddziaływań profilaktycznych. Wybrane aspekty (Olsztyn 2015), Social education: current problems and perspectives (Wilno, 2014), Rodzina. Uzależnienia. Bezpieczeństwo. Studium socjopedagogiczne (Olsztyn, 2013), Rodzina. Przeobrażenia, problemy-pomoc (Elbląg 2013), Społeczno-pedagogiczne aspekty życia rodziny (Olsztyn 2012), Rodzina. Wybrane wymiary środowiska wychowawczego dziecka (Elbląg 2011), Sukcesy i porażki w edukacji dzieci i młodzieży (Olsztyn, 2010), Różne oblicza funkcjonowania szkoły (Olsztyn 2010). Członkini rad naukowych pism: „Journal of Human Dignity and Wellbeing” oraz „Education Sciences and Psychology". Adres e-mailowy: malgorzata.p_z@interia.pl. 